\title{
Microbial food web dynamics in response to a Saharan dust event: results from a mesocosm study in the oligotrophic Mediterranean Sea
}

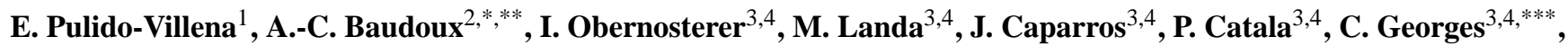 \\ J. Harmand ${ }^{5,6}$, and C. Guieu ${ }^{7,8}$ \\ ${ }^{1}$ Aix-Marseille Université, Université de Toulon, CNRS/INSU, IRD, MIO, UM 110, 13288, Marseille, CEDEX 09, France \\ ${ }^{2}$ Université de Brest; Institut Universitaire Européen de la Mer, IUEM; Laboratoire des Sciences de l'Environnement Marin, \\ UMR 6539 LEMAR, Technopôle Brest Iroise, Copernic, 29280 Plouzané, France \\ ${ }^{3}$ Sorbonne Universités, UPMC Univ Paris 06, UMR 7621, Laboratoire d'Océanographie Microbienne, \\ 66650 Banyuls/mer, France \\ ${ }^{4}$ CNRS, UMR 7621, Laboratoire d'Océanographie Microbienne, 66650 Banyuls/mer, France \\ ${ }^{5}$ Laboratoire de Biotechnologie de l'Environnement-INRA, UR0050, avenue des étangs 11100 Narbonne, France \\ ${ }^{6}$ MODEMIC research team, UMR MISTEA, SUPAGRO, 2 place Viala 34060 Montpellier CEDEX 2, France \\ ${ }^{7}$ Laboratoire d'Océanographie de Villefranche/Mer (LOV), CNRS-INSU, UMR7093, Observatoire Océanologique, \\ 06230 Villefranche-sur-Mer, France \\ ${ }^{8}$ Université Pierre et Marie Curie-Paris 6, UMR 7093, LOV, Observatoire Océanologique, \\ 06230 Villefranche-sur-Mer, France \\ *now at: CNRS, UMR7144, Station Biologique de Roscoff, Place Georges Teissier, 29680 Roscoff, France \\ ** now at: Sorbonne Universités, UPMC Univ Paris 06, UMR7144, Station Biologique de Roscoff, Place Georges Teissier, \\ 29680 Roscoff, France \\ *** now at: Laboratoire d'Océanologie et Géoscience (LOG), UMR CNRS 8187, Université du Littoral Côte d'Opale (ULCO), \\ 32 avenue Foch, 62930 Wimereux, France
}

Correspondence to: E. Pulido-Villena (elvira.pulido@univ-amu.fr)

Received: 16 December 2013 - Published in Biogeosciences Discuss.: 7 January 2014

Revised: 16 June 2014 - Accepted: 24 July 2014 - Published: 14 October 2014

\begin{abstract}
The significant impact of dust deposition on heterotrophic bacterial dynamics in the surface oligotrophic ocean has recently been evidenced. Considering the central role of bacteria in the microbial loop, it is likely that dust deposition also affects the structure and the functioning of the whole microbial food web. In the frame of the DUNE project, aiming to estimate the impact of dust deposition on the oligotrophic Mediterranean Sea through mesocosm experiments, the main goal of the present paper was to assess how two successive dust deposition events affect the dynamics of the microbial food web. The first dust seeding delivered new $\mathrm{P}$ and $\mathrm{N}$ to the amended mesocosms and resulted in a pronounced stimulation of bacterial respiration. It also induced pronounced, but transient, changes in the bacterial community composition. No significant effects were
\end{abstract}

observed on the abundances of viruses and heterotrophic nanoflagellates. The second dust seeding also delivered new $\mathrm{P}$ and $\mathrm{N}$ to the amended mesocosms, but the effect on the microbial food web was very different. Bacterial respiration remained constant and bacterial abundance decreased. Compositional changes following the second seeding were minor compared to the first one. The decrease in bacterial abundance coincided with an increase in virus abundance, resulting in higher virus : bacteria ratios throughout the second seeding period. Our study shows that dust deposition to the surface oligotrophic ocean may involve important modifications of the trophic links among the components of the microbial food web with presumed consequences on $\mathrm{C}$ and nutrient cycling. 


\section{Introduction}

Nutrient cycles control the strength of the biological carbon pump through which $\mathrm{CO}_{2}$ is consumed in surface water and transported as sinking organic carbon to the deep sea (Balino et al., 2001). Therefore, understanding what governs nutrient cycles in the ocean and to which extent climate change plays a role in this schema is essential to understand the oceanic carbon cycle and to predict its evolution. Increasing evidence indicates that not only phytoplankton but also heterotrophic bacteria are limited by inorganic nutrients, mainly $\mathrm{P}$, in oligotrophic oceanic systems (Rivkin and Anderson, 1997; Thingstad et al., 1998; Sala et al., 2002; Obernosterer et al., 2003; Zohary et al., 2005) thus suggesting that the supply of these resources could explain variability in bacterial activity.

Dust deposition is recognized as a significant source of macro- and micro-nutrients to the surface ocean (Jickells et al., 2005; Mahowald et al., 2008). The recent effort to understand the role of these inputs on ocean biogeochemistry has focused on the impact on autotrophic productivity, given their potential to generate new production. However, recent studies combining field and experimental approaches have demonstrated significant increase in heterotrophic bacterial abundance and respiration following dust deposition in oligotrophic ecosystems (Pulido-Villena et al., 2008; Lekunberri et al., 2010; Romero et al., 2011). Moreover, heterotrophic processes appear to be more stimulated by dust pulses compared to autotrophic processes with increasing degree of oligotrophy, the dominant response being modulated by the competition for nutrients between phytoplankton and bacteria (Marañón et al., 2010). Considering the central role of bacteria in the microbial loop (Azam, 1998), it is likely that dust deposition also affects the structure and, importantly, the functioning of the whole microbial food web. To our knowledge, no studies have so far documented the consequences of dust pulses on the dynamics of the microbial food web (including viruses, heterotrophic nanoflagellates) and, thus, the fate of bacterial production after a dust pulse remains unexplored.

Both viruses and heterotrophic nanoflagellates can be significant sources of bacteria mortality in oligotrophic oceanic systems (Zhang et al., 2007; Bonilla-Findji et al., 2009; Boras et al., 2009, 2010). Both loss processes are densitydependent and will thereby be affected by the abundance of heterotrophic bacteria (e.g., Vaqué et al., 1994; Murray and Jackson, 1994). Dust-induced changes in bacterial dynamics may thus indirectly modify the rates of grazing and viral lysis. In addition, physical interactions of bacteria-virusnanoflagellates with inorganic particles can also shift the relative impact of grazing and viruses on bacterial mortality (Salter et al., 2011). Understanding the relative contribution of the losses due to viruses and heterotrophic nanoflagellates is critical because each of these processes influence the functioning of the microbial C pump in different ways (Fuhrman,
1999; Wilhem and Suttle, 2000). Grazing channels bacterial biomass to the higher trophic levels whereas viral lysis transforms this living biomass into dissolved organic matter that can be readily incorporated by non-infected bacteria. This viral shunt has been shown to result in a net increase in bacterial respiration and decrease in growth efficiency (Middelboe et al., 2006; Motegi et al., 2009). The dynamics of the microbial food web may thus play a much larger role in the connections between dust and the ocean carbon cycle than previously recognized.

The Mediterranean Sea is a typical LNLC (Low Nutrient Low Chlorophyll) region, particularly well adapted to tackle the question of the role of atmospheric input: it is an oligotrophic, quasi-enclosed basin, which receives a noticeable atmospheric flux of Aeolian soil dust, mainly derived from the Sahara desert, in the form of strong pulses (Löye-Pilot et al., 1986; Guerzoni et al., 1999). Moreover, during the stratification period, the Mediterranean Sea exhibits a severe nutrient depletion after the spring bloom, and both bacterioplankton and phytoplankton are strongly P-limited and/or N-P co-limited (Thingstad et al., 1998; Sala et al., 2002; Van Wambeke et al., 2009; Tanaka et al., 2011; Moutin et al., 2012).

The DUNE project aimed at estimating the impact of dust deposition on an oligotrophic system, the Mediterranean Sea, based on mesocosm experiments simulating strong atmospheric inputs of desert dust. In the frame of this project, the main goal of the present paper was to assess how two successive dust deposition events affect the dynamics of the microbial food web in oceanic surface waters under oligotrophic conditions.

\section{Material and methods}

\subsection{Experimental design and sampling}

An experimental dust addition into large mesocosms $\left(52 \mathrm{~m}^{3}\right.$, $15 \mathrm{~m}$ depth) was conducted between 26 June and 9 July 2010 in the frame of the DUNE project (DUNE-R experiment, www.obs-vlfr.fr/LOV/DUNE, Guieu et al. 2014, this issue). The DUNE-R experiment was carried out in the Scandola Nature Reserve (Corsica, France), an oligotrophic site (chl $a=0.1 \mu \mathrm{g} \mathrm{L}^{-1}$, Guieu et al., 2014, this issue) protected from human influence. Three replicate mesocosms (hereafter "D-mesocosms") were amended one first time with $41 \mathrm{~g}$ of mineral dust mimicking a high but realistic flux of $10 \mathrm{~g} \mathrm{~m}^{-2}$ (Guieu et al., 2014). A second identical seeding was performed $168 \mathrm{~h}$ after the first one in order to test the hypothesis that changes in the biogeochemical conditions of the water column induced by a dust pulse can modify the impact of a successive dust pulse. Three other mesocosms (hereafter, "C-mesocosms") served as controls. A detailed justification of this strategy and a description of the dust used for the experiment can be found in Guieu et al. (2010, 
2014). Briefly, mineral dust deposition was mimicked using the finest fraction $(<20 \mu \mathrm{m})$ of alluvial soils collected in a desert soil source area in south Tunisia known to export Aeolian dust to the western Mediterranean (Guieu et al., 2010). Dust was subjected to physico-chemical transformations through condensation/evaporation cycles that involved $\mathrm{HNO}_{3}$ and $\mathrm{H}_{2} \mathrm{SO}_{4}$, mimicking atmospheric transport (Guieu et al., 2010). This evapocondensed dust contained on average $0.045 \pm 0.015 \%$ of $\mathrm{P}, 2.31 \pm 0.04 \%$ of $\mathrm{Fe}$ and $1.19 \pm 0.05 \%$ of $\mathrm{N}$, in weight. The amendment of the dust mesocosms in the DUNE-R experiment was performed with the dust mixed with $2 \mathrm{~L}$ of ultrapure water in order to mimic a wet deposition event.

Samples from the six mesocosms were taken just before the first dust addition and at $24 \mathrm{~h}$ interval times during 7 days starting $4 \mathrm{~h}$ after the first amendment. A schematic picture of the sampling strategy can be found in Guieu et al. (2014). Seawater was also collected outside the mesocosms (hereafter "OUT") at selected times during the experiment in order to check for any contamination inside the mesocosms. Filtered seawater $(<0.2 \mu \mathrm{m}$, Sartobran cartridge filter $)$ for dissolved inorganic phosphorus (DIP) analyses and unfiltered seawater for bacterial abundance (BA), bacterial respiration (BR), bacterial community structure, virus abundance (VA), and heterotrophic nanoflagellate abundance (HNFA) was collected using a trace metal-clean Teflon pump system. Samples for DIP, BA and VA were collected at three different depths $(0,5$ and $10 \mathrm{~m})$ whereas samples for BR, HNFA and bacterial community structure were collected at $5 \mathrm{~m}$ depth.

\subsection{Dissolved inorganic phosphorus (DIP) analysis}

DIP was analyzed by spectrophotometry (Murphy and Riley, 1962; Zhang and Chi, 2002) using a long waveguide capillary cell (LWCC). In the recent years, a number of studies focusing on the analytical accuracy of the LWCC technique for measuring DIP have demonstrated a good agreement with the MAGIC technique (Li and Hansell, 2008) and negligible interference with arsenate and silicate (Li and Hansell, 2008; Ma et al., 2009). The used LWCC was $2 \mathrm{~m}$ long and the technique achieved a limit of detection ( $\mathrm{LOD}=$ three times the standard deviation of 10 measurements of the blank) of $1 \mathrm{nmol} \mathrm{L}^{-1}$. More details on the analytical procedure can be found in Pulido-Villena et al. (2010).

\subsection{Enumeration of heterotrophic bacteria, heterotrophic nanoflagellates and viruses}

For heterotrophic bacterial abundance (BA), duplicate subsamples $(1.8 \mathrm{~mL})$ were fixed with formaldehyde ( $2 \%$ final concentration), kept at $4{ }^{\circ} \mathrm{C}$ for $30 \mathrm{~min}$, quick-frozen in liquid nitrogen and then stored at $-80^{\circ} \mathrm{C}$ until flow cytometry analysis as described in Lebaron et al. (2001). Heterotrophic bacterial counts were performed with the FACSCalibur flow cytometer (Becton Dickinson) equipped with an air-cooled ar- gon laser $(488 \mathrm{~nm}, 15 \mathrm{~mW})$. Bacterial cells were stained with SYBR Green I (Invitrogen - Molecular Probes) at $0.025 \%$ ( $\mathrm{vol} / \mathrm{vol}$ ) final concentration for $15 \mathrm{~min}$ at room temperature in the dark. Stained bacterial cells were discriminated and enumerated according to their right-angle light scatter (SSC) and green fluorescence measured at $530 / 30 \mathrm{~nm}$. In a plot of green fluorescence versus red fluorescence, we were able to distinguish photosynthetic from non-photosynthetic bacteria. The volume analyzed was around $15 \mu \mathrm{L}$ at low speed. The cell abundance was determined from the flow rate, which was calculated by weighing one tube of Milli-Q water before and after a $5 \mathrm{~min}$ run of the cytometer. The flow rate was determined after every five samples. Fluorescent beads $(1.002 \mu \mathrm{m}$; Polysciences Europe) were systematically added to each analyzed sample as an internal standard.

For the enumeration of heterotrophic nanoflagellates (HNFA), samples $(3.8 \mathrm{~mL})$ were fixed with glutaraldehyde ( $1 \%$, final concentration), incubated for $30 \mathrm{~min}$ at $4{ }^{\circ} \mathrm{C}$, quick-frozen in liquid nitrogen and then stored at $-80^{\circ} \mathrm{C}$ until flow cytometric analyses following the protocol described in Christaki et al. (2011). HNF counts were performed with the FACSCanto II flow cytometer (Becton Dickinson) equipped with three air-cooled lasers: blue (argon $488 \mathrm{~nm})$, red $(633 \mathrm{~nm})$ and violet $(407 \mathrm{~nm})$. Staining was performed with SYBR Green I (Invitrogen - Molecular Probes) at $0.05 \%(v / v)$ final concentration for $15-30 \mathrm{~min}$ at room temperature in the dark. The volume analyzed was around $1 \mathrm{~mL}$ at high speed (around $100 \mu \mathrm{L} \mathrm{min}^{-1}$ ) for 10 to $30 \mathrm{~min}$ to obtain a minimum of 600 events.

For virus counts (VA), samples $(1 \mathrm{~mL})$ were fixed with glutaraldehyde $(0.5 \%$ final concentration) incubated for $15 \mathrm{~min}$ at $4{ }^{\circ} \mathrm{C}$, frozen in liquid nitrogen and stored at $-80^{\circ} \mathrm{C}$ until flow cytometric analysis according to Brussaard (2004). Virus counts were performed on a FACSCalibur flow cytometer (Becton Dickinson). Numbers were corrected for the blank consisting of TE buffer with autoclaved $0.02 \mu \mathrm{m}$ filtered seawater in the correct dilution. Data were analyzed using the freeware CYTOWIN (http://www.sbroscoff.fr/Phyto/index.php?option= com_content\&task=view\&id=72\&Itemid=123).

\subsection{Bacterial respiration}

Samples from $5 \mathrm{~m}$ depth of each mesocosm were gently filtered through a $0.8 \mu \mathrm{m}$ PC filter under low vacuum pressure, and the filtrate was siphoned into a set of six BOD bottles. Three BOD bottles from each mesocosm were immediately fixed with Winkler reagents, and the rest were incubated in the dark in a tap water bath to minimize temperature variations. All the incubated BOD bottles were fixed with Winkler reagents after $24 \mathrm{~h}$. Oxygen concentration was measured through a spectrophotometric approach based on measuring the absorbance at $466 \mathrm{~nm}$ of the colored $\mathrm{I}_{2}$ and $\mathrm{I}_{3}^{-}$(Labasque et al., 2004; Reinthaler et al., 2006). The concentration of oxygen was calculated by comparing the absorbance in a 
sample against standards of known oxygen content made from $0.0467 \mathrm{~mol} \mathrm{~L}^{-1}$ potassium iodate $\left(\mathrm{KIO}_{3}\right)$ solutions.

\subsection{Bacterial diversity}

For bacterial diversity, volumes of $500 \mathrm{~mL}$ were sampled every 2 days in the mesocosms at $5 \mathrm{~m}$ depth. Seawater was filtered through $0.8 \mu \mathrm{m}$ filters $(47 \mathrm{~mm}$ polycarbonate (PC) filters, Nuclepore, Whatman), and bacterial cells were collected from the $<0.8 \mu \mathrm{m}$ filtrate on $0.2 \mu \mathrm{m}$ PC filters $(47 \mathrm{~mm}$ PC; Nuclepore, Whatman). Filters were stored at $-80^{\circ} \mathrm{C}$ until analysis. DNA and RNA extraction, amplification as well as CE-SSCP analysis were performed as described in Laghdass et al. (2011).

Filters were plunged in lysis buffer (40 mM EDTA, $50 \mathrm{mM}$ Tris, $0.75 \mathrm{M}$ sucrose) and underwent three freeze and thaw cycles using liquid nitrogen and a $65^{\circ} \mathrm{C}$ water bath. They were then incubated with a freshly prepared lysozyme solution $\left(2 \mathrm{mg} \mathrm{mL}^{-1}\right.$ final) during $45 \mathrm{~min}$ at $37^{\circ} \mathrm{C}$ under gentle agitation. Proteinase $\mathrm{K}\left(0.2 \mathrm{mg} \mathrm{mL}^{-1}\right.$ final) and SDS (1\% final) were added, and a second incubation $\left(1 \mathrm{~h}, 55^{\circ} \mathrm{C}\right)$ was performed. DNA and RNA were coextracted using an Allprep DNA/RNA Mini Kit (Qiagen) according to the manufacturer's instructions. To avoid DNA contamination in the RNA fraction, a DNase step was performed during RNA extraction, using the RNase-free DNase set from Qiagen and following the kit's instructions. The quality and concentration of DNA and RNA were checked by agarose gel electrophoresis $(1 \%)$, and DNA was stored at $-20^{\circ} \mathrm{C}$.

For RNA samples, denaturation was performed by adding reverse primer w34 (5'-TTA CCG CGG CTG CTG GCA C-3') (Lee et al., 1996) (1 $\mu \mathrm{M}$ final concentration) to $13 \mu \mathrm{L}$ of RNA before incubation at $94{ }^{\circ} \mathrm{C}$ for $5 \mathrm{~min}$ followed by rapid cooling on ice. Reverse transcription was achieved by adding dNTPs ( $0.8 \mu \mathrm{M}$ final concentration), MMLV reverse transcriptase and 5X MMLV buffer (Promega) and incubating the samples at $42^{\circ} \mathrm{C}$ for $1 \mathrm{~h}$. The cDNA samples were stored at $-20^{\circ} \mathrm{C}$.

DNA and cDNA were amplified using the bacterial specific primers w49 forward (5'-ACG GTC CAG ACT CCT ACG GG-3') (Delbes et al., 2000) and reverse w34 (see above), targeting about $200 \mathrm{bp}$ of the V3 region of the $16 \mathrm{~S}$ rRNA gene. W34 was $5^{\prime}$-labeled with TET to enable detection. Polymerase chain reactions (PCRs) contained $1 \mu \mathrm{L}$ of DNA or cDNA, $0.3 \mu \mathrm{M}$ primers, $0.8 \mu \mathrm{M}$ dNTPs, pfu DNA polymerase (1U final), pfu buffer (1X, Promega), and UVsterilized Milli-Q water (QS $50 \mu \mathrm{L}$ ). The PCR protocol we used was $1 \mathrm{~min}$ at $94^{\circ} \mathrm{C}$ followed by 25 cycles of $30 \mathrm{~s}$ at $94^{\circ} \mathrm{C}, 30 \mathrm{~s}$ at $61^{\circ} \mathrm{C}$ and $30 \mathrm{~s}$ at $72^{\circ} \mathrm{C}$ with a final extension of $10 \mathrm{~min}$ at $72^{\circ} \mathrm{C}$. Amplification products were verified by agarose gel electrophoresis (1\%) and their concentrations estimated by comparison with molecular size markers (Smart Ladder, Promega).

For analysis of 16S rRNA genes and transcripts in CE$\mathrm{SSCP}$, samples were diluted and $1 \mu \mathrm{L}$ of each dilution was mixed with $18.8 \mu$ l of deionized formamide (Hi-Di formamideTM; Applied Biosystems) and $0.2 \mu \mathrm{l}$ of the internal size standard GeneScan-400HD (Rox) (Applied Biosystems). A denaturation step of $5 \mathrm{~min}$ at $94{ }^{\circ} \mathrm{C}$ was performed, and samples were immediately placed in a water/ice bath for $10 \mathrm{~min}$. Fragments were separated by CE-SSCP as described previously (Delbes et al., 2000) using an ABI 310 Genetic Analyzer (Applied Biosystems) with electrophoresis at $12 \mathrm{kV}$ and $30^{\circ} \mathrm{C}$ for $30 \mathrm{~min}$ per sample. The electropherograms were analyzed by the GeneScan software (Applied Biosystems), and the obtained profiles were aligned and normalized using the Rox internal standard with SAFUM (Zemb et al., 2007). Operational taxonomic units (OTUs) were defined for peaks reaching at least 150 fluorescence units, that is, three times the value of the base line. Peaks with identical retention times between samples were considered one identical OTU. For the fingerprints obtained from the 16S rRNA gene, we refer in the following to the total community, and for the fingerprints obtained from the 16S rRNA transcripts we refer to the active community.

\subsection{Statistical analysis}

To explore dust-induced changes in the study parameters, we checked for significant differences between the Cmesocosms and the D-mesocosms immediately after each seeding (up to day 2 and up to day 8; pairwise Student's $t$ test) and during the whole first and second seeding periods (up to day 6 and from day 7 to the end, respectively, Student's $t$ test grouped comparison). During the first seeding period, the comparison between C- and D-mesocosms gives information on the effect of the first seeding. During the second seeding period, the comparison between C- and Dmesocosms gives information on the combined effect of both performed seedings. We followed dust-induced changes in the composition of the total and active bacterial community using the following approach. Our fingerprinting approach provided the relative abundances of OTUs, based on their contributions to the total peak area, in three D-mesocosms and three $\mathrm{C}$-mesocosms for each time point. We first tested for each OTU whether its relative abundance was significantly different between treatments at a given time point (Students $t$ test, $p<0.05$ ). For any OTU that was significantly different between treatments, we calculated its mean relative abundance in the D- and C- mesocosms, and then the difference in the relative abundance as $D_{\text {mean }}-C_{\text {mean }}$. This difference could be positive - that is the relative abundance of a given OTU is higher in the D-treatment compared to the C-treatment - or negative - that is the relative abundance of a given OTU is lower in the D-treatment compared to the C-treatment. To weigh these relative changes, we expressed them as percent of the total peak area of the control community. Summing all positive or negative changes allowed us to illustrate the overall extent of change induced by dust addition. 
Table 1. Initial biogeochemical conditions of seawater in the DUNE-R experiment (average for C-, D-mesocosms and OUT samples). DIP: dissolved inorganic phosphorus; DL: detection limit $\left(0.03 \mu \mathrm{M}\right.$ for $\left.\mathrm{NO}_{3}^{-}\right)$. Values for chlorophyll $a$, DIP, $\mathrm{NO}_{3}^{-}$and $\mathrm{dFe}$ data are average concentrations at surface, $5 \mathrm{~m}$ and $10 \mathrm{~m}$ depth. Value for primary production is the mean rate at $5 \mathrm{~m}$ depth.

\begin{tabular}{ll}
\hline & DUNE-R \\
\hline Chlorophyll $a, \mu \mathrm{g} \mathrm{L}^{-1}$ & $0.07 \pm 0.02^{\mathrm{a}}$ \\
Primary production, $\mathrm{mg} \mathrm{C} \mathrm{m}^{-3} \mathrm{~d}^{-1}$ & $3.89 \pm 0.46^{\mathrm{b}}$ \\
$\mathrm{DIP}, \mathrm{nM}$ & $5 \pm 3$ \\
$\mathrm{NO}_{3}^{-}, \mu \mathrm{M}$ & $<\mathrm{DL}^{\mathrm{b}}$ \\
$\mathrm{dFe}^{\mathrm{nM}}$ & $3.3 \pm 0.8^{c}$ \\
\hline
\end{tabular}

${ }^{a}$ From Guieu et al. (2014), ${ }^{b}$ from Ridame et al. (2014), ${ }^{c}$ from Wuttig et al. (2013).

\section{Results}

\subsection{Biogeochemical characteristics of the study site}

A detailed description of the main environmental conditions encountered during the DUNE-R experiment can be found in Guieu et al. (2014). Briefly, seawater temperature during the whole experiment ranged between 20.0 and $27.3^{\circ} \mathrm{C}$, with a significant increase in surface temperature and well-stratified waters towards the end of both seeding periods. At the beginning of the experiment, chl $a$ averaged $0.07 \mu \mathrm{g} \mathrm{L}^{-1}$, nitrate concentration was below the limit of detection of the used technique $(30 \mathrm{nM})$ and dissolved iron averaged $3.3 \mathrm{nM}$ (Guieu et al., 2014, Table 1). The first dust seeding resulted in a 1.9-fold increase in the chl $a$ concentration in the D-mesocosms compared to the C-mesocosms. The second seeding induced an additional increase, yielding up to a 2.4-fold higher chl $a$ concentration in the D-mesocosms as compared to the C-mesocosms (Guieu et al., 2014). Nitrate concentration increased in the D-mesocosms to $3 \mu \mathrm{M}$ after the first seeding and then decreased to $0.5 \mu \mathrm{M}$ by the end of the first seeding period. The second seeding induced a greater increase in nitrate concentration (up to $10 \mu \mathrm{M}$ ) (Ridame et al., 2014). The initial iron values before the dust addition varied between 2.2 and $4.4 \mathrm{nmol} \mathrm{L}^{-1}$ inside the mesocosms and outside. The first seeding resulted in a decrease of dissolved iron, whereas the second addition of dust induced dissolution of Fe from the dust particles (Wuttig et al., 2013).

Dissolved inorganic phosphorus (DIP) concentration was $5 \pm 2 \mathrm{nM}$ (mean value of OUT samples and D- and Cmesocosms at the three depths) before the seeding. Ten hours after the first seeding, depth-averaged DIP concentration increased in the D-mesocosms to $9 \pm 1 \mathrm{nM}$ and decreased to initial values $(4 \pm 1 \mathrm{nM})$ in the following sampling $(23 \mathrm{~h}$ after the seeding) and, thereafter, remained constant until the end of the first phase of the experiment (Fig. 1). At the end of the first seeding period, DIP was homogeneous among C- and D-mesocosms and OUT station, averaging $4 \pm 2 \mathrm{nM}$
(Fig. 1). Regarding the second seeding, DIP increased significantly in surface and $5 \mathrm{~m}$ depth after $5 \mathrm{~h}$. Contrary to the first seeding, DIP in D-mesocosms remained fairly constant and significantly higher than in C-mesocosms until the end of the experiment (Fig. 1). While for the first seeding the increase in DIP was similar among the three mesocosms, the second seeding induced a higher inter-mesocosm variability.

\subsection{Bacterial abundance and respiration}

Before the first seeding, bacterial abundance (BA) in the six mesocosms and in OUT samples averaged $4.7 \pm 0.410^{5}$ cell $\mathrm{mL}^{-1}$ (all depths). Throughout the experiment, BA was slightly higher in OUT samples than inside the mesocosms at all depths. BA behaved differently after the two conducted dust seedings. One day after the first seeding, there was a significant 1.2-fold difference in BA in D-mesocosms compared to C-mesocosms at the surface $(t(4)=3.8, p<0.05)$, whereas no significant differences were observed between $\mathrm{D}$ and C-mesocosms at 5 and $10 \mathrm{~m}$ depth. During the rest of the first seeding period, no significant differences in BA between $\mathrm{C}$ - and D-mesocosms were observed at any of the study depths. By contrast, during the second seeding period, BA in D-mesocosms showed substantial variability (a decrease was observed in two out of three mesocosms), but it was, on average, significantly lower than in C-mesocosms at the surface (1.1-fold, $t(34)=2.4, p<0.05), 5 \mathrm{~m}(1.1$-fold, $t(34)=3.9$, $p<0.001)$ and $10 \mathrm{~m}$ depth $(1.1$-fold, $t(34)=2.5, p<0.01)$ (Fig. 2).

Bacterial respiration (BR), determined only at $5 \mathrm{~m}$ depth,

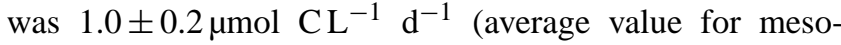
cosms and OUT sample) before the seeding, and it exhibited similar values between OUT samples and C-mesocosms throughout the experiment. After the first dust amendment, BR was enhanced by 3.5-fold in D-mesocosms compared to $\mathrm{C}$-mesocosms, and it remained significantly higher, on average $(t(27)=6.7, p<0.001)$, until the last available sampling point (10 days after the seeding). No additional increase in BR was observed after the second dust amendment (Fig. 3).

\subsection{Bacterial community structure}

We observed a pronounced change in the bacterial community composition 4 days after the first seeding, and changes were minor after the second seeding (Fig. 4a). After 4 days, the relative abundance of 4 OTUs was significantly higher in the $\mathrm{D}$ - than in the $\mathrm{C}$-mesocosms, and the relative abundance of 8 OTUs was significantly lower in the D- than in the Cmesocosms. The sum of the dust-induced changes accounted for up to $55 \%$ of the total community 4 days after the first seeding, while it was $<22 \%$ after the second seeding. Dustinduced changes of the active bacterial community revealed a similar pattern following the first seeding with a marked response after 4 days (Fig. 4b). A second remarkable change 

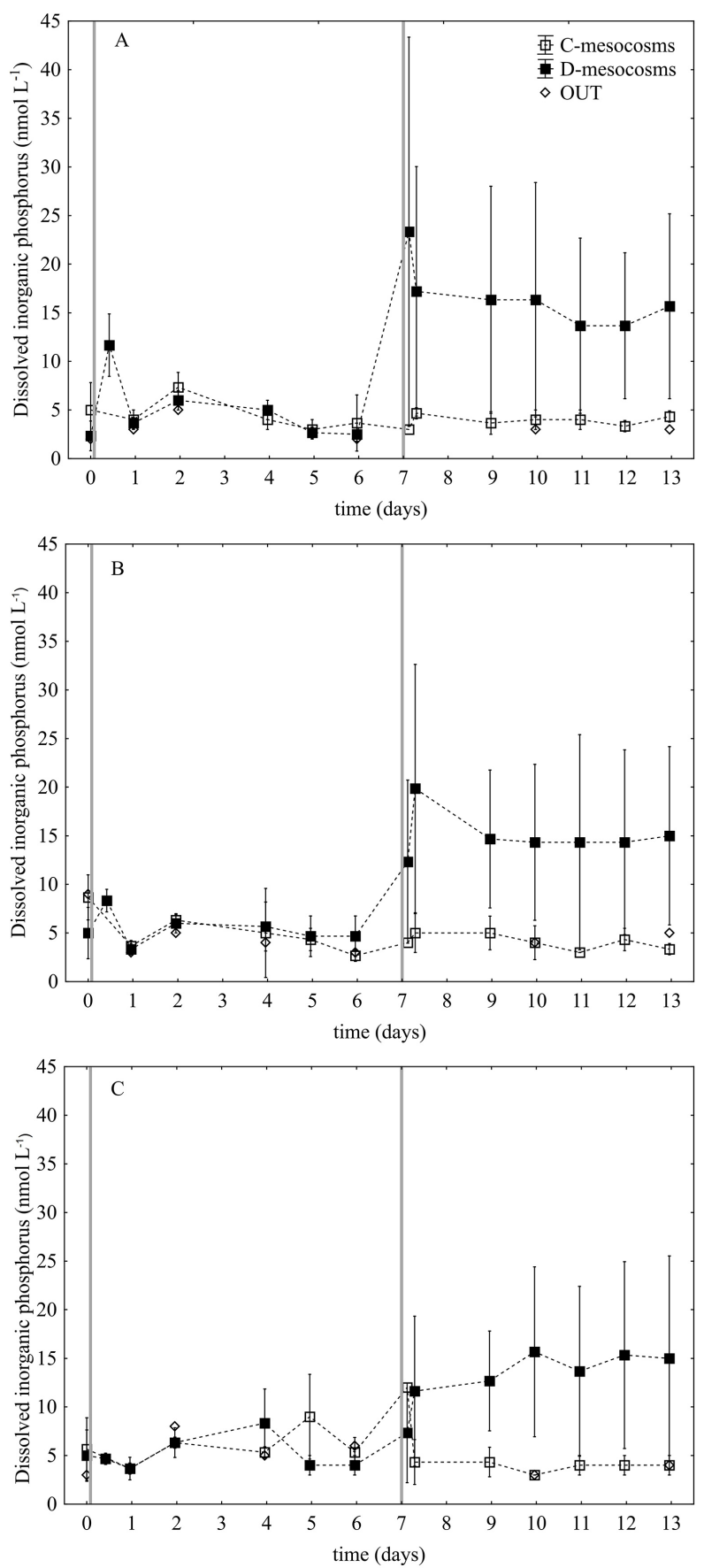

Figure 1. Dissolved inorganic phosphorus (nM, mean \pm standard deviation of three replicate mesocosms) in D- and C-mesocosms and OUT samples at surface (a), $5 \mathrm{~m}$ (b) and $10 \mathrm{~m}$ (c) depth during the DUNE-R experiment. Grey vertical bars represent the dust seedings.

was detectable at day 13 corresponding to 6 days after the second seeding.

We used the Simpson index to evaluate whether changes in the number of OTUs and their relative contributions occurred in response to dust addition. Our results reveal that dust ad-
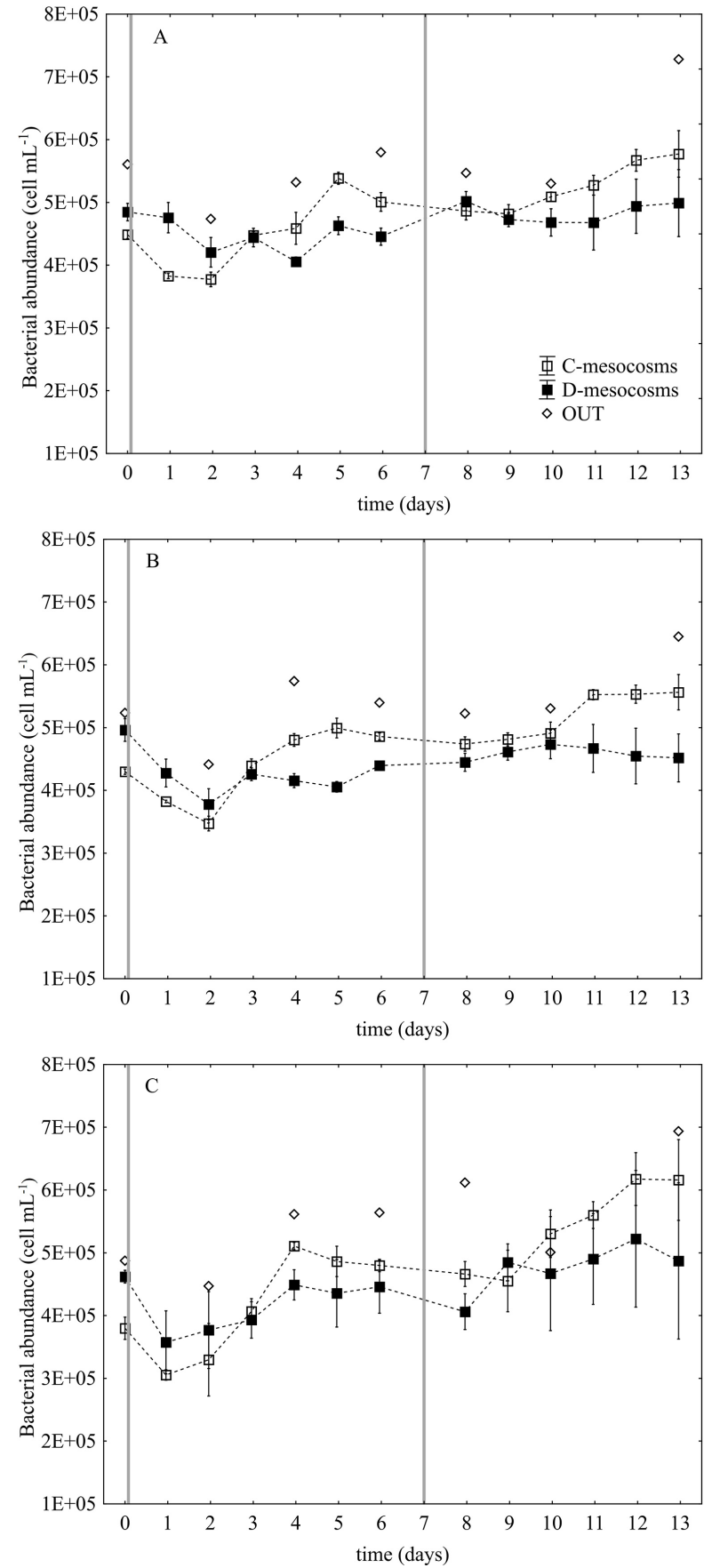

Figure 2. Bacterial abundance (cell $\mathrm{mL}^{-1}$, mean \pm standard deviation of three replicate mesocosms) in D- and C-mesocosms and OUT samples at surface (a), $5 \mathrm{~m}$ (b) and $10 \mathrm{~m}$ (c) depth during the DUNE-R experiment. Grey vertical bars represent the dust seedings.

dition had no effect on the diversity of the total and active bacterial community (Fig. 5). Diversity of the total community decreased during the first 11 days of the experiment, then rapidly increased. This pattern was less pronounced for the diversity of the active community. 


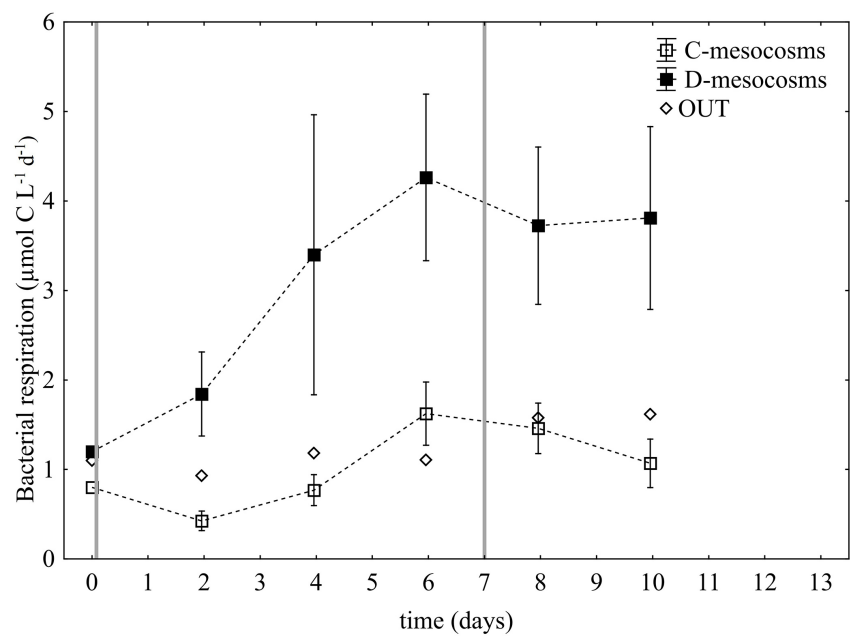

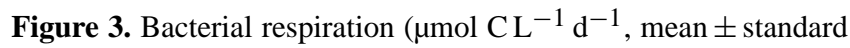
deviation of three replicate mesocosms) in D- and C-mesocosms and OUT samples at $5 \mathrm{~m}$ depth during the DUNE-R experiment. Grey vertical bars represent the dust seedings.

\subsection{Virus and heterotrophic nanoflagellate abundance}

Before the first seeding, total virus abundance (VA) in the six mesocosms and in OUT samples averaged $3.5 \pm 0.410^{6}$ particles $\mathrm{mL}^{-1}$ (all depths, Fig. 6). VA at the station OUT was slightly lower than in $\mathrm{C}$-mesocosms during the course of the experiment. In C-mesocosms, VA remained quite stable except for two steep decreases in abundance observed at day 2 and day 11 (at all depths). No significant differences in VA were observed in D-mesocosms compared to Cmesocosms during the first dust seeding period at any of the study depths. However, during the second seeding period, VA was, on average, significantly higher in D-mesocosms than in C-mesocosms at surface (1.1-fold, $t(34)=2.4, p<0.05$ ) and $5 \mathrm{~m}$ depth (1.1-fold, $t(34)=2.4, p<0.05)$ (Fig. 6). The observed higher VA was associated with a concomitant lower in BA in D-mesocosms, resulting in significantly higher virus to bacteria ratio in D-mesocosms than in C-mesocosms during the second seeding period at surface $(t(34)=3.0$, $p<0.01), 5 \mathrm{~m}$ depth $(t(34)=2.4, p<0.05)$ and $10 \mathrm{~m}$ depth $(t(34)=2.9, p<0.01)$ (Fig. 7).

The abundance of heterotrophic nanoflagellates (HNFA), determined only at $5 \mathrm{~m}$ depth, varied during the duration of the experiment between 196 and 1000 cell $\mathrm{mL}^{-1}$. HNFA was higher in OUT samples than inside the mesocosms throughout the experiment. Similar dynamics were observed for Cand D-mesocosms, and there were no significant differences in HNFA between both treatments at any of the seeding periods (Fig. 8).
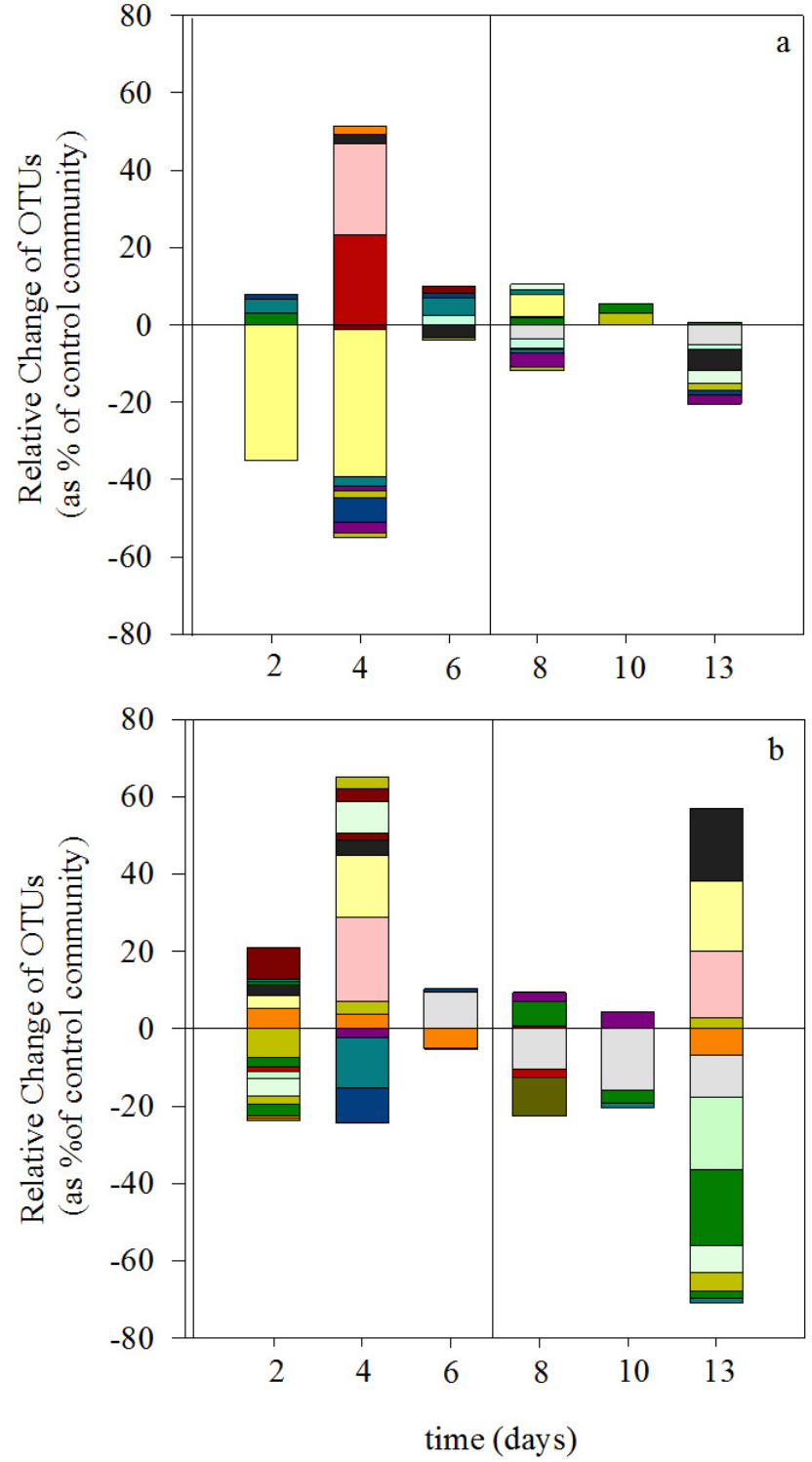

Figure 4. Changes in the relative abundance of total (a) and active (b) OTUs in response to dust addition at $5 \mathrm{~m}$ depth during the DUNE-R experiment. Positive changes indicate higher, and negative changes indicate lower relative abundance in dust than in control mesocosms. Changes in relative abundances are expressed as percent of the total community. Only OTUs with significantly different relative abundances in the dust and control-mesocosms are shown. See Material and Methods for more details.

\section{Discussion}

\subsection{Effect of dust on inorganic nutrients}

The successive dust seedings performed during the DUNE$\mathrm{R}$ experiment induced distinct modifications in the biogeochemical conditions of the study waters. Generally, both seedings resulted in increased concentrations of dissolved inorganic phosphorus (DIP, this study) and nitrate $\left(\mathrm{NO}_{3}^{-}\right.$, 


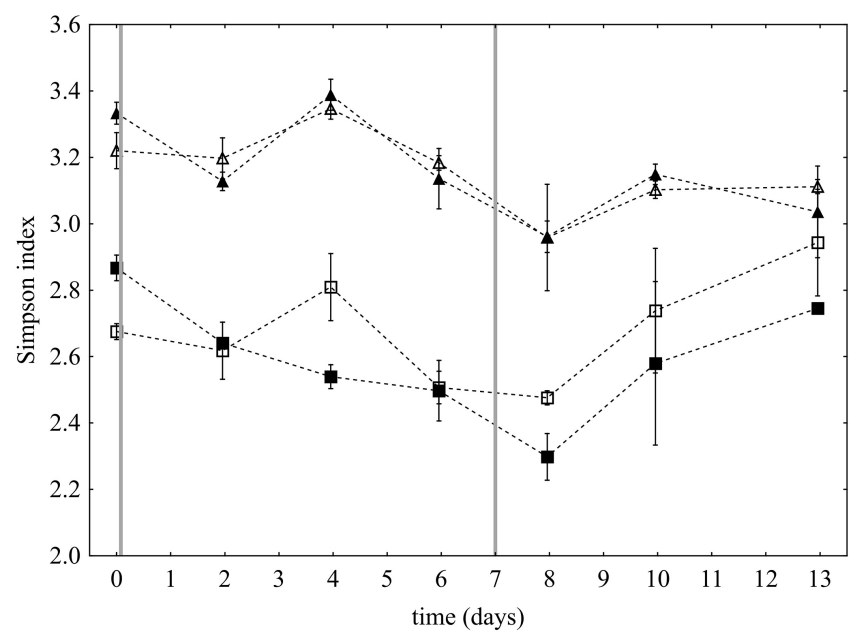

Figure 5. Diversity (Simpson index) of the total (squares) and active (triangles) bacterial community in D- (filled symbols) and Cmesocosms (empty symbols) at $5 \mathrm{~m}$ depth during the DUNE-R experiment. Grey vertical bars represent the dust seedings.

Ridame et al., 2014) concentrations. However, the intensity of these effects was notably different between the seedings, with greater differences between D- and C- mesocosms observed after the second seeding. The homogeneity among mesocosms of the concentrations in DIP and $\mathrm{NO}_{3}^{-}$introduced by dust differed also between the first and second seeding periods. While after the first seeding, the effect was similar among the three D-mesocosms, a clear response was only observed in two (D1 and D2) out of the three mesocosms during the second seeding.

At the beginning of the experiment, the DIP and $\mathrm{NO}_{3}^{-}$concentrations ( $5 \mathrm{nM}$ and $\leq 30 \mathrm{nM}$, respectively) would suggest a N-limitation or N-P co-limitation of the biological activity $(\mathrm{N}: \mathrm{P}$ ratio $\leq 6)$. The dust used for the seedings exhibits a total $\mathrm{N}$ : P ratio of 55 (Guieu et al. 2014). Assuming a $100 \%$ dissolution of N (Ridame et al., 2014) and a $15 \%$ dissolution of P (Ridame and Guieu, 2002; Pulido-Villena et al., 2010), the seeding would have delivered new $\mathrm{N}$ and $\mathrm{P}$ at a $\mathrm{N}: \mathrm{P}$ ratio of 350, and would have pushed the system towards a strong $\mathrm{P}$-limitation. Indeed, the $\mathrm{N}: \mathrm{P}$ ratio in the D-mesocosms increased to ca. 300 after the first seeding, and it was further enhanced to 500 at the end of the first seeding period and during most part of the second one. $\mathrm{N}: \mathrm{P}$ ratios decreased to values around 16 at the end of the experiment. The higher delivery of $\mathrm{N}$ relative to $\mathrm{P}$ through atmospheric deposition has been evoked as responsible, in part, for the high $\mathrm{N}: \mathrm{P}$ ratios encountered in the Mediterranean Sea, particularly in the eastern basin (Krom et al., 2010; Markaki et al., 2010). Although estimated N : P ratios in DUNE dust (350) are substantially higher than reported for atmospheric deposition in western (50) and eastern (100) basins (Markaki et al., 2010), these results would confirm the contribution of atmospheric
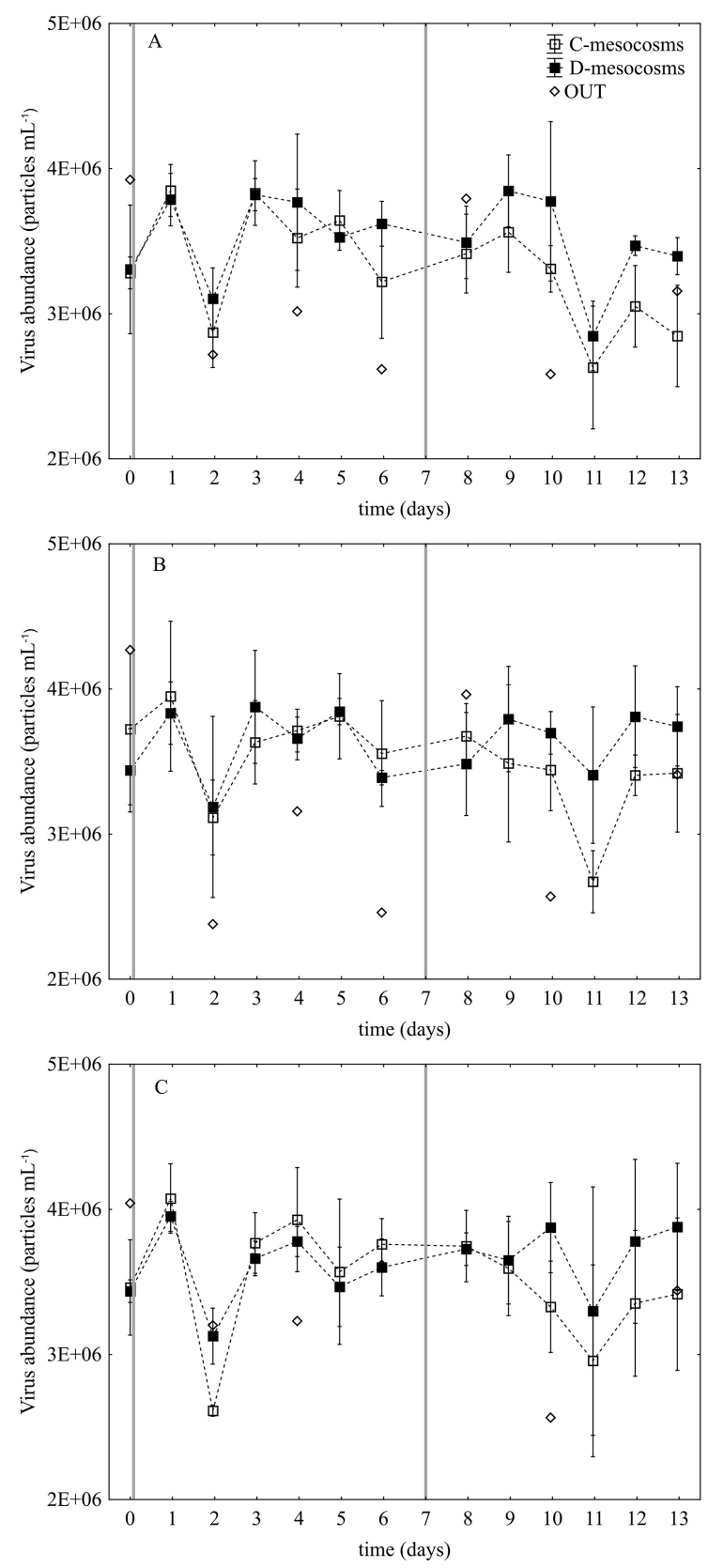

Figure 6. Virus abundance (particle $\mathrm{mL}^{-1}$, mean \pm standard deviation of three replicate mesocosms) in D- and C-mesocosms and OUT samples at surface (a), $5 \mathrm{~m}$ (b) and $10 \mathrm{~m}$ (c) depth during the DUNE-R experiment. Grey vertical bars represent the dust seedings.

deposition in determining $\mathrm{N}: \mathrm{P}$ ratios in the Mediterranean Sea.

\subsection{Pronounced response of bacterial respiration}

Bacterial respiration revealed the most pronounced response to dust addition, while the responses of heterotrophic bacteria and virus abundances were moderate and restricted to the 


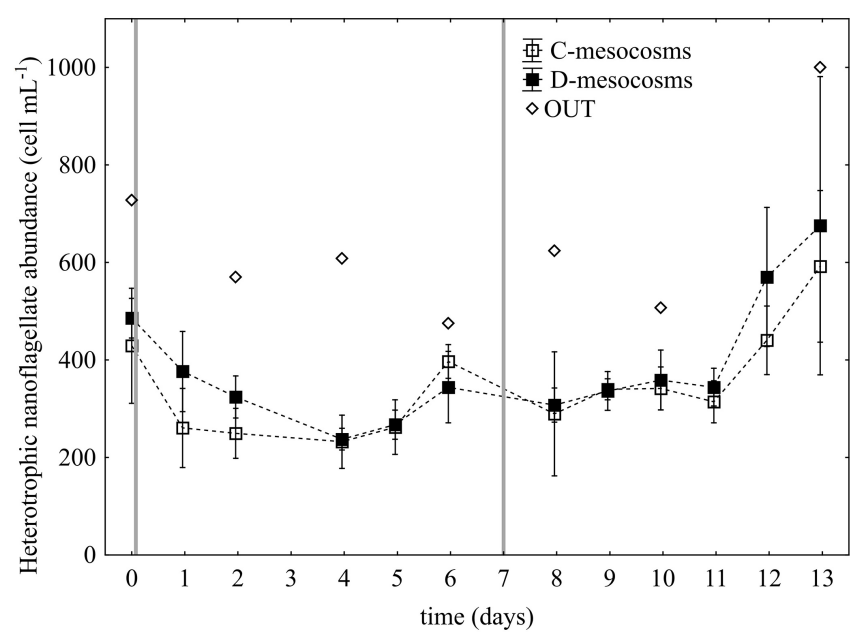

Figure 7. Ratios virus and bacterial abundance (mean \pm standard deviation of three replicate mesocosms) in D- and C-mesocosms and OUT samples at surface (a), $5 \mathrm{~m}$ (b) and $10 \mathrm{~m}$ (c) depth during the DUNE-R experiment. Grey vertical bars represent the dust seedings.

second seeding period. A strong stimulation of BR by dust pulse has already been reported for the open Mediterranean Sea (Pulido-Villena et al., 2008), and the observed response agrees with previous studies showing clearer responses of metabolic rates and weaker responses in terms of biomass (Herut et al., 2005; Lekunberri et al., 2010; Marañón et al., 2010; Laghdass et al., 2011). Given the N : P ratios encountered in the study site at the beginning of the DUNE-R experiment, heterotrophic bacterial activity would have been presumably limited by the availability of DIP or co-limited by $\mathrm{N}$ and P. Indeed, bacterial activity has been generally reported to be P-limited in the Mediterranean Sea (e.g., Thingstad et al., 1998; Sala et al., 2002) although recent studies have pointed to a N-P co-limitation (Tanaka et al., 2011). In this regard, the first seeding period seems to be characterized by a bottom-up control of bacterial dynamics with an increase in BA and BR just after the dust amendment.

Whether dust addition stimulated directly or indirectly bacterial respiration constitutes a key question for this study. The rapid decrease of DIP introduced by the first seeding and concomitant increase in BA after 2 days suggests a direct effect due to the addition of the limiting nutrient $\mathrm{P}$. However, the extent of increase in bacterial respiration, and the still high bacterial respiration rates recorded during the second seeding, when $\mathrm{P}$ was not consumed, would also suggest an indirect effect by phytoplankton. Phytoplankton was stimulated by the first and the second dust addition (Ridame et al., 2014). Bacterial respiration could have been stimulated by labile phytoplankton-derived dissolved organic matter (DOM). Besides C, phytoplankton DOM also provides N and P, offering an alternate source of the limiting element to bacteria.
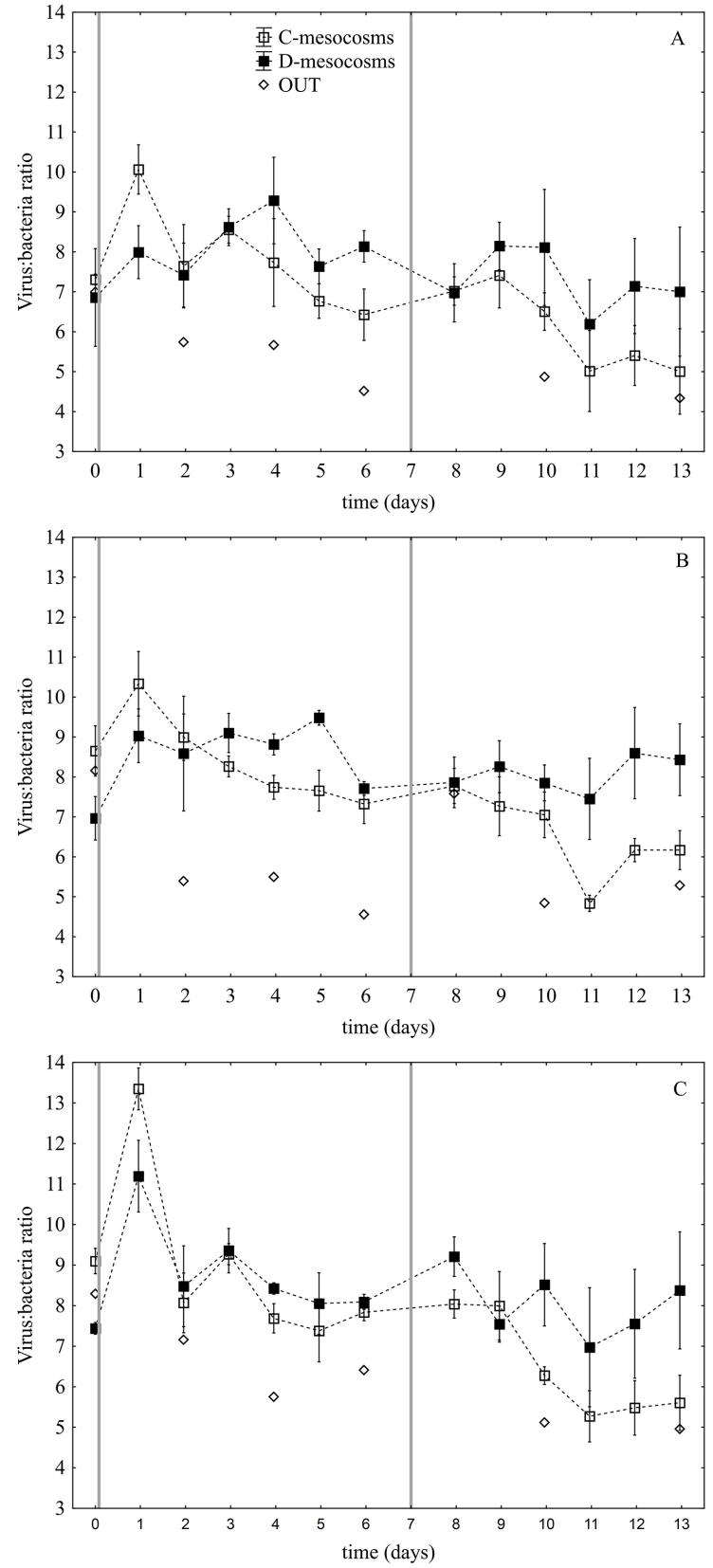

Figure 8. Heterotrophic nanoflagellate abundance (cell $\mathrm{mL}^{-1}$, mean \pm standard deviation of three replicate mesocosms) in dustand control-mesocosms and OUT samples at $5 \mathrm{~m}$ depth during the DUNE-R experiment. Grey vertical bars represent the dust seedings.

The switch to this source could explain the non-utilization of DIP during the second seeding.

\subsection{Effect of dust on bacterial community composition}

The first dust addition induced rapid but transient changes in bacterial community composition, and changes following the second seeding were minor. This pattern reflects a 

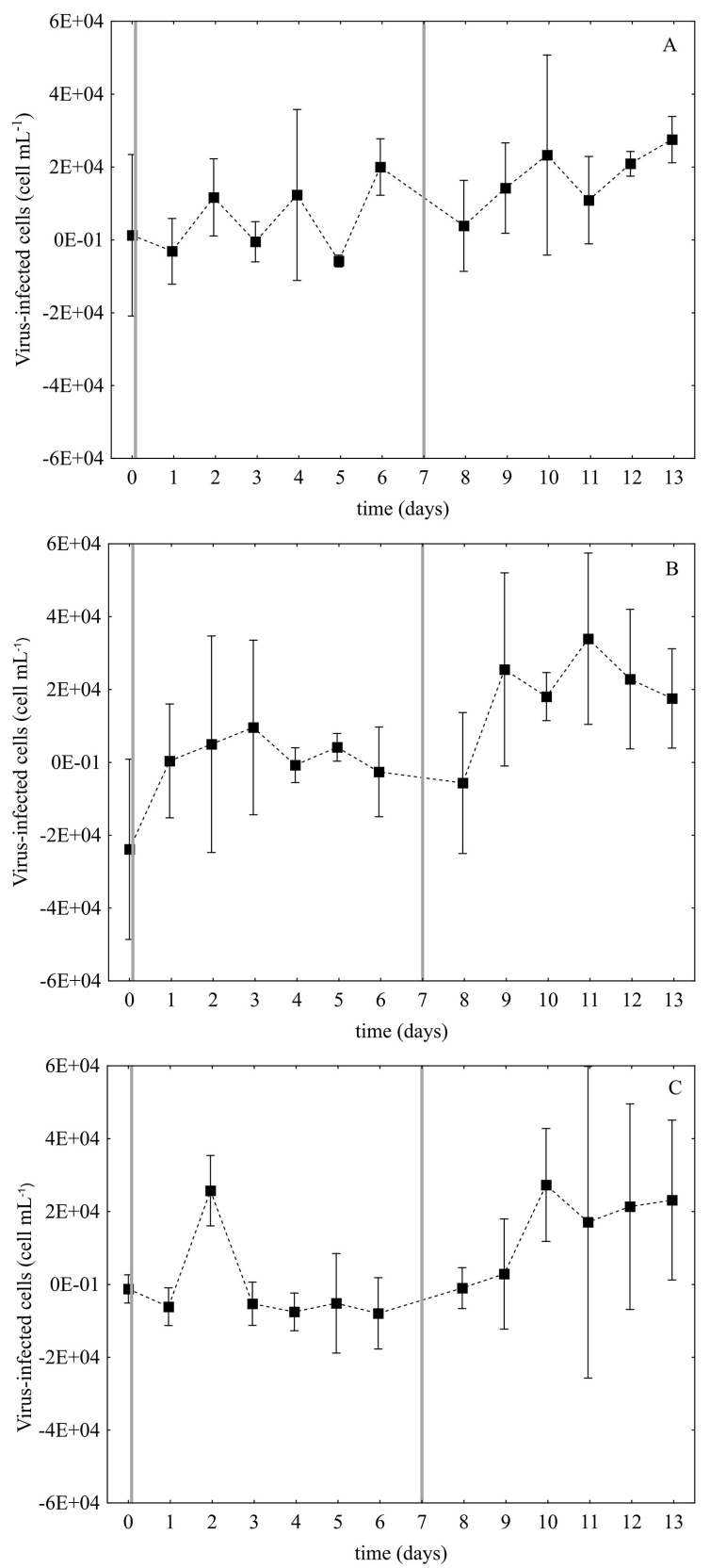

Figure 9. Theoretical calculation of viral infected bacterial abundance (cell $\mathrm{mL}^{-1}$, mean \pm standard deviation of three replicate mesocosms) based on the dust-induced changes in VA (VAdust VAcontrol) at surface (a), $5 \mathrm{~m}$ (b) and $10 \mathrm{~m}$ (c) depth during the DUNE-R experiment and a conservative burst size of 20 (Parada et al., 2006). Grey vertical bars represent the dust seedings.

rather short-term response to the environmental conditions set by the first seeding, such as those related to inorganic nutrient conditions and/or phytoplankton growth. Our results are in line with observations from microcosm studies where the effect of dust was followed over 2-3 days. Dust addition to surface waters of the central Atlantic Ocean stim- ulated Roseobacter and Gammaproteobacteria, and lead to a decrease in SAR11 after 2 days of incubation (Marañón et al., 2010). Similarly, metabolic rates of Prochlorococcus and a bacterial population dominated by SAR11 were reduced upon dust addition in the North Atlantic Ocean (Hill et al., 2010). In a microcosm experiment performed in the NW Mediterranean Sea, the dust-induced changes detectable after 3 days were similar to those obtained in P-amended microcosms suggesting that the response was mainly driven by P (Lekunberri et al., 2010). In a previous mesocosm study performed in June 2008 at the same site (DUNE1), but with a lower temporal sampling resolution, bacterial communities collected 8 days after the seeding did not reveal any marked differences (Laghdass et al. 2011). Together, these results indicate that dust addition can selectively stimulate certain bacterial groups, probably by providing specific conditions favorable for their growth. However, the present study demonstrates that these changes are transient, and that consecutive dust deposition events greatly diminish the initial bacterial response.

\subsection{Divergent responses of viruses and HNF dynamics to dust addition}

Slight differences were observed in virus and HNF abundance between OUT samples and inside the mesocosms. This may be caused by enclosure effects, but does not preclude from extracting valid patterns of response of viruses and HNF dynamics to dust addition. Although both heterotrophic bacteria and phytoplankton clearly responded to the first seeding, neither HNF nor viruses appeared to be impacted, at least in terms of abundance. By contrast, the second seeding was associated with moderate but significantly higher virus abundance (VA) while HNF dynamics remained unchanged. Viral dynamics result from the balance between loss and production processes. The observed higher standing stock of virus might result either from a reduced decay rate or a stimulated production of viruses in the D-mesocosms. The latter hypothesis seems more plausible as the observed higher VAs were associated with a concomitant decrease in bacterial abundance (BA). Dust-induced changes in VA (VAdust VAcontrol) correlate significantly with dust-induced changes in BA (BAdust - BAcontrol) at all depths, during the second seeding period (surface: $r=-0.55, p<0.05 ; 5 \mathrm{~m}: r=$ $-0.59, p<0.01 ; 10 \mathrm{~m}: r=-0.65, p<0.01)$. Although viral production on heterotrophic bacteria was not monitored, this strong relationship suggests a possible viral mediated control of the bacterial community during the second dust amendment. Theoretical calculation of the \% of infected bacteria using the dust-induced changes in VA and a conservative burst size of 20 (Parada et al., 2006) would actually explain 23 to $90 \%$ (average $45 \%$ ) of the observed decrease in bacterial abundance during the second seeding period (Fig. 9). Altogether, these results suggest that the second seeding stimulated viral lysis of bacteria and, thereby, shifted 
the balance of bottom-up and top-down controls of the bacteria production.

Although few field studies have inferred simultaneous rates of viral lysis and HNF grazing in oligotrophic settings, bacteria mortality due to viruses appears to be a more variable process than HNF grazing (Bonilla-Findji et al., 2009; Boras et al., 2009, 2010). For example, a time-series study conducted in a coastal oligotrophic system recorded enhanced rates of viral lysis with increasing bacterial abundance and production whereas concomitant rates of $\mathrm{HNF}$ grazing remained constant (Boras et al., 2009). Factors responsible for increased viral proliferation are the relative host-virus abundance (Murray and Jackson, 1992), these hosts' activity (Middelboe et al. 2000) and the induction of prophage (i.e., phages integrated into their host genome), ultimately leading to the lysis of lysogenic bacteria (Paul, 2008; Williamson et al., 2002). The second dust addition induced an enhanced viral production while bacterial respiration and community composition remained unchanged. This uncoupling between bacterial and viruses responses would favor the hypothesis of an induction of prophages. A significant proportion of inducible lysogenic bacteria was indeed reported in oligotrophic ecosystems (Jiang and Paul, 1996; Paul, 2008) including the Mediterranean Sea (Weinbauer et al., 2003). Although the mechanisms that result in prophage induction are not well constrained, several studies suggested that this process might be governed by the changes in host metabolic status (Williamson et al., 2002; Oppenheim et al., 2005). Particularly relevant to our study, Boras et al. (2009) evidenced that the addition of $\mathrm{P}$ to nutrient-poor waters could be a factor inducing lysogenic cells in natural bacterial communities. In the present study, the addition of $\mathrm{P}$ by dust addition could have induced prophage upon the second amendment, but the lack of response of the virus community to the first seeding remains puzzling. Altogether, these results indicate that dust deposition can cause substantial modifications of the trophic interactions within the microbial loop.

\section{Summary and conclusions}

Our results confirm previous evidence that heterotrophic bacteria play a crucial role within the connections between dust deposition and ocean carbon cycle. In oligotrophic systems, where $\mathrm{C}$ export in the dissolved form can be equal to or higher than particulate C export (Carlson et al., 1994), the stimulation of bacterial respiration by dust pulses may decrease the amount of DOC susceptible to be exported to depth through winter mixing. In addition, by enhancing bacterial activity, dust deposition may modify bacterial processing of dissolved organic matter and, thus, its residence time in the water column, with consequences on the efficiency of the microbial carbon pump (MCP; Jiao et al., 2010). Process studies devoted to the bacterial transformation of DOM after dust pulses would allow the parameterization of the links between dust deposition and the MCP in the oligotrophic ocean.

Our study also shows that the dust deposition to the surface ocean can shape the trophic links among the components of the microbial food web. If, as indicated by our results, viral lysis is stimulated by dust addition, this would have crucial consequences on the cycling of DOC and the remineralization of nutrients. Indeed, the consequences of such an effect may include the re-mineralization and release of macro- and micro-nutrients to the water column and/or the decrease in the export of particulate $\mathrm{C}$ due to the conversion of organic matter from the particulate to the dissolved phase (Fuhrman, 1999; Middelboe et al., 2000; Wilhelm and Suttle, 2000).

Our study shows that the effects of dust deposition on ocean carbon cycle are not restricted to a simple response of autotrophic phytoplankton and/or heterotrophic bacteria. They may involve important modifications of the trophic links, particularly within the microbial food web, with crucial consequences on $\mathrm{C}$ and nutrient cycling.

Acknowledgements. This work is a contribution of the DUNE experiment (a DUst experiment in a low Nutrient, low chlorophyll Ecosystem, $\quad$ http://www.obs-vlfr.fr/LOV/DUNE/index.html) and was funded by the LEFE, UPMC and ANR-DUNE under the contract ANR-07-BLAN-0126-01. DUNE was endorsed by the international SOLAS (Surface Ocean - Lower Atmosphere) program in February 2009, (http://www.solas-int.org/activities/project-endorsement.html). We would like to sincerely thank the Réserve naturelle de Scandola, Parc naturel régional de Corse, in particular J. M. Dominici and collaborators, for professionalism and cooperation in the implementation of the field work in the bay of Elbo. We thank all of the participants of the DUNE-2 experiment for their involvement. The service charges for this open access publication have been covered by CNRS-INSU and the Laboratoire d'Océanographie de Villefranche (LOV), CNRS UMR7093.

Edited by: E. Marañón

\section{References}

Azam, F.: Microbial control of oceanic carbon flux: The plot thickens, Science, 280, 694-696, 1998.

Balino, B., Fasham, M., and Bowles, M.: Ocean biogeochemistry and global change: JGOFS research highlights 1988-2000, IGBP Science 2, 1-32, 2001.

Bonilla-Findji, O., Herndl, G. J., Gattuso, J.-P., and Weinbauer, M. G.: Viral and Flagellate Control of Prokaryotic Production and Community Structure in Offshore Mediterranean Waters, Appl. Env. Microbiol., 75, 4801-4812, 2009.

Boras, J. A., Sala, M. M., Vázquez-Domínguez, E., Weinbauer, M. G., and Vaqué D.: Annual changes of bacterial mortality due to viruses and protists in an oligotrophic coastal (NW Mediterranean, Environ. Microbiol., 11, 1181-1193, 2009.

Boras, J. A., Sala, M. M., Baltar, F., Aristegui, J., Duarte, C. M., and Vaqué D.: Effect of viruses and protists on bacteria in eddies of 
the Canary Current region (subtropical northeast Atlantic), Limnol. Oceanogr., 55, 885-898, 2010.

Brussaard, C. P. D.: Optimization of procedures for counting viruses by flow cytometry, Appl. Environ. Microbiol., 70, 1506-1513, 2004.

Carlson, C. A., Ducklow, H. W., and Michales, A. F.: Annual flux of dissolved organic carbon from the euphotic zone in the Northwestern Sargasso Sea, Nature, 371, 405-408, 1994.

Christaki, U., Courties, C., Massana, R., Catala, P., Lebaron, P., Gasol, J. M., and Zubkov, M. V.: Optimized routine flow cytometric enumeration of heterotrophic flagellates using SYBR Green I, Limnol. Oceanogr. Methods, 9, 329-339, 2011.

Delbes, C., Moletta, R., and Godon, J. J.: Monitoring of activity dynamics of an anaerobic digester bacterial community using 16S rRNA polymerase chain reaction-single-strand conformation polymorphism analysis, Environ. Microbiol., 2, 506-515, 2000.

Fuhrman, J.: Marine viruses and their biogeochemical and ecological effects, Nature, 399, 541-548, 1999.

Guerzoni, S., Chester, R., Dulac, F., Herut, B., Loye-Pilot, M. D., Measures, C., Migon, C., Molinaroli, E., Moulin, C., Rossini, P., Saydam, C., Soudine, A., and Ziveri, P.: The role of atmospheric deposition in the biogeochemistry of the Mediterranean Sea, Prog. Oceanogr., 44, 147-190, 1999.

Guieu, C., Dulac, F., Ridame, C., and Pondaven, P.: Introduction to project DUNE, a DUst experiment in a low Nutrient, low chlorophyll Ecosystem, Biogeosciences, 11, 425-442, doi:10.5194/bg11-425-2014, 2014.

Herut, B., Zohary, T., Krom, M. D., Mantoura, R. F. C., Pitta, P., Psarra, S., Rassoulzadegan, F., Tanaka, T., and Thingstad, T. F.: Response of East Mediterranean surface water to Saharan dust: On-board microcosm experiment and field observations, Deep Sea Res. (II), 52, 3024-3040, 2005.

Hill, P. G., Zubkov, M. V., and Purdie, D. A.: Differential responses of Prochlorococcus and SAR11-dominated bacterioplankton groups to atmospheric dust inputs in the tropical Northeast Atlantic Ocean, Fems Microbiol. Lett., 306, 82-89, 2010.

Jiang, S. C. Paul, J. H.: The abundance of lysogenic bacteria in marine microbial communities as determined by prophage induction, Mar. Ecol. Prog. Ser., 142, 27-38, 1996.

Jiao, N., G. J. Herndl, G. J., Hansell, D. A., Benner, R., Kattner, G., Wilhem, S. W., Kirchman, D. L., Weinbauer, M. G., Luo, T., Chen, F., and Azam, F.: Microbial production of recalcitrant dissolved organic matter: long-term carbon storage in the global ocean, Nat. Rev. Microbiol., 8, 593-598, 2010.

Jickells, T. D., An, Z. S., Andersen, K. K., Baker, A. R., Bergametti, G., Brooks, N., Cao, J. J., Boyd, P.W., Duce, R.A., Hunter, K.A., Kawahata, H., Kubilay, N., laRoche, J., Liss, P.S., Mahowald, N., Prospero, J. M., Ridgwell, A. J., Tegen, I., and Torres, R.: Global iron connections between desert dust, ocean biogeochemistry, and climate, Science, 308, 67-71, 2005.

Krom, M. D., Emeis, K. C., and Van Cappellen, P.: Why is the Eastern Mediterranean phosphorus limited?, Prog. Oceanogr., 85, 236-244, 2010.

Labasque, T., Chaumery, C., Aminot, A., and Kergoat, G.: Spectrophotometric Winkler determination of dissolved oxygen: reexamination of critical factors and reliability, Mar. Chem., 88, 53-60, 2004.
Laghdass, M., Blain, S., Besseling, M., Catala, P., Guieu, C., and Obernosterer, I.: Effects of Saharan dust on the microbial community during a large in situ mesocosm experiment in the NW Mediterranean Sea, Aquat. Microb. Ecol., 62, 201-213, 2011.

Lebaron, P., Servais, P., Agogue, H., Courties, C., and Joux, F.: Does the high nucleic acid content of individual bacterial cells allow us to discriminate between active cells and inactive cells in aquatic systems?, Appl. Environ. Microbiol., 67, 1775-1782, 2001.

Lekunberri, I., Lefort, T., Romero, E., Vazquez-Dominguez, E., Romera-Castillo, C., Marrase, C., Peters, F., Weinbauer, M., and Gasol, J. M.: Effects of a dust deposition event on coastal marine microbial abundance and activity, bacterial community structure and ecosystem function, J. Plank. Res., 32, 381-396, 2010.

Li, Q. P. and Hansell, D. A.: Intercomparison and coupling of magnesium-induced co-precipitation and long-path liquidwaveguide capillary cell techniques for trace analysis of phosphate in seawater, Anal. Chim. Ac., 611, 68-72, 2008.

Löye-Pilot, M. D., Martin, J. M., and Morelli, J.: Influence of Saharan dust on the rain acidity and atmospheric input to the Mediterranean, Nature, 321, 427-428, 1986.

Ma, J., Yuan, D. X., Zhang, M., and Liang, Y.: Reverse flow injection analysis of nanomolar soluble reactive phosphorus in seawater with a long path length liquid waveguide capillary cell and spectrophotometric detection, Talanta, 78, 315-320, 2009.

Mahowald, N., Jickells, T. D., Baker, A. R., Artaxo, P., BenitezNelson, C., Bergametti, G., Bond, T. C., Chen, Y., Cohen, D. D., Herut, B., Kubilay, N., Losno, R., Luo, C., Maenhaut,W., McGee, K. A., Okin, G. S., Siefert, R. L., and Tsukuda, S.: The global distribution of atmospheric phosphorus sources, concentrations and deposition rates and anthropogenic impacts, Global Biogeochem. Cy., 22, GB4026, doi:10.1029/2008GB003240, 2008.

Marañón, E., Fernandez, A., Mourino-Carballido, B., MartinezGarcia, S., Teira, E., Cermeno, P., Choucino, P., Huete-Ortega, M., Fernandez, E., Calvo-Diaz, A., Moran, X. A. G., Bode, A., Moreno-Ostos, E., Varela, M. M., Patey, M. D., and Achterberg, E. P.: Degree of oligotrophy controls the response of microbial plankton to Saharan dust, Limnol. Oceanogr., 55, 2339-2352, 2010.

Markaki, Z., Loye-Pilot, M. D., Violaki, K., Benyahya, L., and Mihalopoulos, N.: Variability of atmospheric deposition of dissolved nitrogen and phosphorus in the Mediterranean and possible link to the anomalous seawater N / P ratio, Mar. Chem., 120, 187-194, 2010.

Middelboe, M.: Bacterial growth rate and marine virus host dynamics, Microb. Ecol., 40, 114-124, 2000.

Middelboe, M. and Jørgensen, N. O. G.: Viral lysis of bacteria: an important source of dissolved amino acids and cell wall compounds', J. Mar. Biol. Ass. UK, 86, 605-612, 2006.

Motegi, C., Nagata, T., Miki, T., Weinbauer, M.G., Legendre, L., and Rassoulzadegan, F.: Viral control of bacterial growth efficiency in marine pelagic environments, Limnol. Oceanogr., 54, 1901-1910, 2009.

Moutin, T., Van Wambeke, F., and Prieur, L.: Introduction to the Biogeochemistry from the Oligotrophic to the Ultraoligotrophic Mediterranean (BOUM) experiment, Biogeosciences, 9, 38173825, doi:10.5194/bg-9-3817-2012, 2012.

Murphy, J. and Riley, J.: A modified single solution method for the determination of phosphate in natural waters, Anal. Chim. Acta, 27, 31-36, 1962. 
Murray, A. G. and Jackson, G. A.: Viral dynamics - a model of the effects of size, shape motion and abundance of single-celled planktonic organisms and other particles, Mar. Ecol. Prog. Ser., 89, 103-116, 1992.

Obernosterer, I., Kawasaki, N., and Benner, R.: P-limitation of respiration in the Sargasso Sea and uncoupling of bacteria from P-regeneration in size-fractionation experiments, Aquat. Microb. Ecol., 32, 229-237, 2003.

Oppenheim, A. B., Kobiler, O., Stavans, J., Court, D. L., and Adhya, S.: Switches in bacteriophage lambda development, Annu. Rev. Genet., 39, 409-429, 2005.

Parada, V., Herndl, G. J., and Weinbauer, M. G.: Viral burst size of heterotrophic prokaryotes in aquatic systems, J. Mar. Biol. Assoc. UK, 86, 613-621, 2006.

Paul, J. H.: Prophages in marine bacteria: dangerous molecular time bombs or the key to survival in the seas?, The ISME J., 2, 579589, 2008.

Pulido-Villena, E., Wagener, T., and Guieu, C.: Bacterial response to dust pulses in the western Mediterranean: Implications for carbon cycling in the oligotrophic ocean, Global Biogeochem. Cy., 22, GB1020, doi:10.1029/2007GB003091, 2008.

Pulido-Villena, E., Rerolle, V., and Guieu, C.: Transient fertilizing effect of dust in P-deficient LNLC surface ocean, Geoph. Res. Lett., 37, L01603, doi:10.1029/2009GL041415, 2010.

Reinthaler, T., Bakker, K., Manuels, R., van Ooijen, J., and Herndl, G. J.: Fully automated spectrophotometric approach to determine oxygen concentrations in seawater via continuous-flow analysis, Limnol. Oceanogr. Methods, 4, 358-366, 2006.

Ridame, C. and Guieu, C.: Saharan input of phosphate to the oligotrophic water of the open western Mediterranean Sea, Limnol. Oceanogr., 47, 856-869, 2002.

Ridame, C., Dekaezemacker, J., Guieu, C., Bonnet, S., L'Helguen, S., and Malien, F.: Phytoplanktonic response to contrasted Saharan dust deposition events during mesocosm experiments in LNLC environment, Biogeosciences Discuss., 11, 753-796, doi:10.5194/bgd-11-753-2014, 2014.

Rivkin, R. B. and Anderson, M. R.: Inorganic nutrient limitation of oceanic bacterioplankton, Limnol. Oceanogr., 42, 730-740, 1997.

Romero, E., Peters, F., Marrasé, C., Guadayol, O., Gasol, J. M., and Weinbauer, M.: Coastal Mediterranean plankton stimulation dynamics through a dust storm event: An experimental simulation, Estuar. Coast. Shelf Sci., 93, 27-39, 2011.

Sala, M., Peters, F., Gasol, J. M., Pedros-Alio, C., Marrasé, C., and Vaqué, D.: Seasonal and spatial variations in the nutrient limitation of bacterioplankton growth in the northwestern Mediterranean, Aquat. Microb. Ecol., 27, 47-56, 2002.

Salter, I., Boettjer, D., and Christaki, U.: The effect of inorganic particle concentration on bacteria-virus-nanoflagellate dynamics, Environ. Microbiol., 13, 2768-2777, 2011.
Tanaka, T., Thingstad, T. F., Christaki, U., Colombet, J., CornetBarthaux, V., Courties, C., Grattepanche, J.-D., Lagaria, A., Nedoma, J., Oriol, L., Psarra, S., Pujo-Pay, M., and Van Wambeke, F.: Lack of P-limitation of phytoplankton and heterotrophic prokaryotes in surface waters of three anticyclonic eddies in the stratified Mediterranean Sea, Biogeosciences, 8, 525-538, doi:10.5194/bg-8-525-2011, 2011.

Thingstad, T. F., Zweifel, U. L., Rassoulzadegan, F.: P limitation of heterotrophic bacteria and phytoplankton in the northwest Mediterranean, Limnol. Oceanogr. 43, 88-94, 1998.

Van Wambeke, F., Ghiglione, J.-F., Nedoma, J., Mével, G., and Raimbault, P.: Bottom up effects on bacterioplankton growth and composition during summer-autumn transition in the open NW Mediterranean Sea, Biogeosciences, 6, 705-720, doi:10.5194/bg-6-705-2009, 2009.

Vaqué, D., Gasol, J. M., and Marrasé, C.: Grazing rates on bacteria: the significance of methodology and ecological factors, Mar. Ecol. Prog. Ser., 109, 263-274, 1994.

Weinbauer, M. G., Brettar, I., and Höfle, M. G.: Lysogeny and virus induced mortality of bacterioplankton in surface, deep, and anoxic marine waters, Limnol. Oceanogr., 48, 1457-1465, 2003.

Wilhelm, S. W. and Suttle, C. A.: Viruses as regulators of nutrient cycles in aquatic environments, in: Microbial biosystems: New frontiers, edited by: Bell, C. R., Brylinsky, M., and JohnsonGreen, P., Atlantic Canada Society of Microbial Ecology., 551556, 2000.

Williamson, S., McDaniel, L., Houchin, L., and Paul, J. H.: Seasonal variation in lysogeny as depicted by prophage induction in Tampa Bay, Florida, Appl. Environ. Microbiol., 68, 4307-4314, 2002.

Wuttig, K., Wagener, T., Bressac, M., Dammshäuser, A., Streu, P., Guieu, C., and Croot, P.L.: Impacts of dust deposition on dissolved trace metal concentrations ( $\mathrm{Mn}, \mathrm{Al}$ and $\mathrm{Fe}$ ) during a mesocosm experiment, Biogeosciences, 10, 2583-2600, doi:10.5194/bg-10-2583-2013, 2013.

Zemb, O., Haegeman, B., Delgenes, J. P., Lebaron, P., and Godon, J. J.: Safum statistical analysis of SSCP fingerprints using PCA projections, dendrograms and diversity estimators, Mol. Ecol. Notes, 7, 767-770, 2007.

Zhang, J. Z. and Chi, J.: Automated analysis of nanomolar concentrations of phosphate in natural waters with liquid waveguide, Environ. Sci. Tech., 36, 1048-1053, 2002.

Zhang, R., Weinbauer, M. G., and Qian, P. Y.: Viruses and flagellates sustain apparent richness and reduce biomass accumulation of bacterioplankton in coastal marine waters, Environ. Microbiol., 9, 2008-2018, 2007.

Zohary, T., Herut, B., Krom, M. D., Mantoura, R. F. C., Pitta, P., Psarra, S., Rassoulzadegan, F., Stambler, N., Tanaka, T., Thingstad, T. F., and Woodward, E. M. S.: P-limited bacteria but $\mathrm{N}$ and $\mathrm{P}$ co-limited phytoplankton in the Eastern Mediterranean microcosm experiment, Deep-Sea Res., 52, 3011-3023, 2005. 